\title{
THE STATE OF THE NEW ZEALAND LABOUR MARKET
}

\author{
David Paterson \\ Labour Market and Business Performance \\ Ministry of Business, Innovation and Employment
}

\begin{abstract}
This paper will review recent developments in the New Zealand labour market and trace the passage of these indicators through the global financial crisis to the outlook for the coming 3 years. The paper is based on the Ministry's Quarterly Labour Market report and Short-term Employment Forecasts. The paper describes a strong labour market. Indicators of labour demand growth have moderated from the elevated levels recorded earlier in 2014, but remain solid. Construction is a significant source of employment demand across the entire country, and not just Canterbury. Migration-led population growth and near-record labour force participation rates are expanding labour supply. Women in general are showing increased involvement in the labour market: the female labour force participation rate returned to its record high of 63.7 per cent (equal to that recorded in March 2014), and the female employment rate (59.7 per cent) is at its highest rate since December 2008. Single mothers in particular have seen a sharp increase in their employment rate, which has reached its highest level since the series began in 1986. High participation is likely slowing the fall in the unemployment rate, which nevertheless hit its lowest level since March 2009. Wage growth remains subdued over the September quarter, but this comes against the backdrop of low inflation.
\end{abstract}

\section{Introduction}

This paper discusses the current state of New Zealand's labour market, by reference to a series of charts. The paper is based on the Ministry of Business Innovation and Employment's (MBIE) latest Quarterly Labour market Report.

The paper will cover:

- the latest labour market indicators

- a look at how we view current economic conditions

- various aspects of labour market demand, supply and matching - currently and over the past 10 years

- and how wages have responded to these

The paper concludes with MBIE's latest labour market forecasts. 


\section{Key Labour Market Indicators}

\begin{tabular}{|l|c|c|c|}
\hline Indicator & September 2014 & Quarterly change & Annual change \\
\hline Employed & $2,346,000$ & $18,000(+0.8 \%)$ & $72,000(+3.2 \%)$ \\
\hline Unemployed & 134,000 & $-4,000(-2.8 \%)$ & $-14,000(-9.6 \%)$ \\
\hline Participation rate (\%) & 69.0 & $+0.1 \mathrm{pp}$. & $+0.4 \mathrm{pp}$. \\
\hline Employment rate (\%) & 65.2 & $+0.2 \mathrm{pp}$. & $+0.8 \mathrm{pp}$. \\
\hline Unemployment rate (\%) & 5.4 & $-0.2 \mathrm{pp}$. & $-0.7 \mathrm{pp}$. \\
\hline
\end{tabular}

Indicators of labour demand growth have moderated from the elevated levels recorded earlier in 2014 (3.7\% p.a.), but remain solid. Construction is a significant source of employment demand across the entire country, and not just in Canterbury. Migration-led population growth and near-record labour force participation rates, particularly for women, are expanding labour supply. High participation is likely slowing the fall in the unemployment rate, which nevertheless hit its lowest level since March 2009 at 5.4\%. The number of unemployed fell 9.6\% over the year.

\section{Economic Conditions}

Figure 1: GDP growth

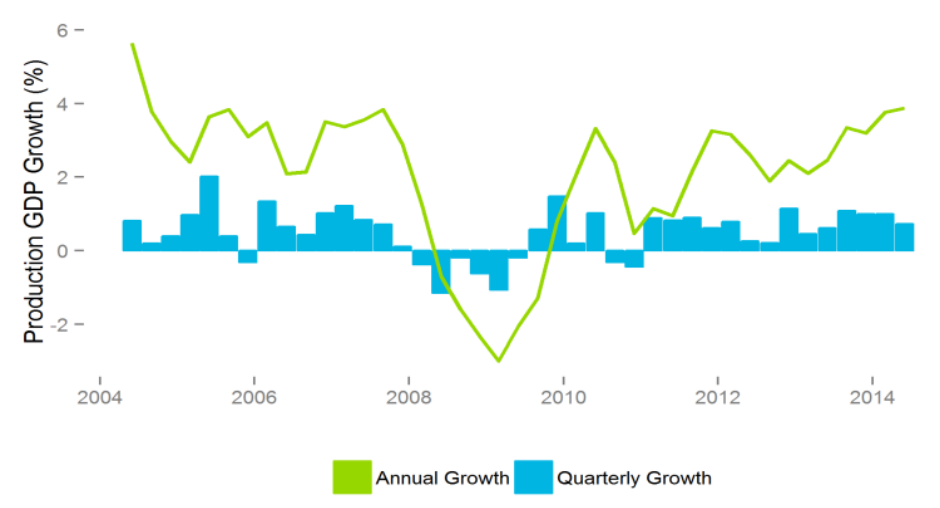

Recent indicators suggest New Zealand's economic growth is robust, yet slowing. GDP increased 0.7 per cent in the June 2014 quarter, down from the 1.0 per cent or greater recorded in the preceding three quarters. Strong domestic demand underpins this growth, while global prospects weakened over the year.

The number of people employed in New Zealand increased by ( 0.8 per cent) over the September quarter, and 3.2 per cent $(72,000$ people) over the year.

Despite this, annual employment growth has actually slowed since the March and June 2014 quarters, which both recorded annual growth of 3.7 per cent, the highest annual increases since December 2004The services sector and construction were the main drivers of GDP growth in the June quarter

Externally, falling commodity prices have contributed to reduced export values. Merchandise exports fell 3.0 per cent over the September quarter, following a 7.5 per cent drop in June. Lower dairy prices were the main contributor to the September fall (dairy export values fell 8.8 per cent, while quantities exported rose 2.7 per cent). 
Business confidence hit record levels around the start of 2014, and has fallen throughout the year. Indicators of actual firm activity have been more buoyant, and hiring intentions remain high. Our interpretation of the business confidence results is that firms are seeing the rate of growth levelling out, rather than expecting a fall in growth.

\section{Labour Demand}

Figure 2: Employment growth

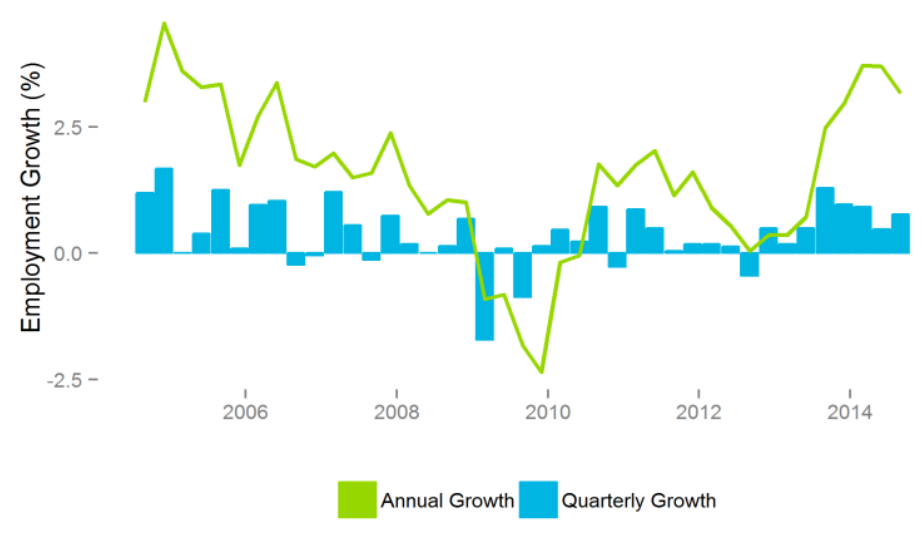

The number of people employed in New Zealand increased by $(0.8$ per cent) over the September quarter, and 3.2 per cent $(72,000$ people) over the year.

Despite this, annual employment growth has actually slowed since the March and June 2014 quarters, which both recorded annual growth of 3.7 per cent, the highest annual increases since December 2004

The main driver of recent employment growth has been full-time employment.

Part-time employment growth was stronger than full-time employment growth at the end of the last business cycle (around 2007), but growth for both types of employment stalled during the recession. Since 2012, full-time employment growth has been strong, while part-time employment growth has been volatile. 


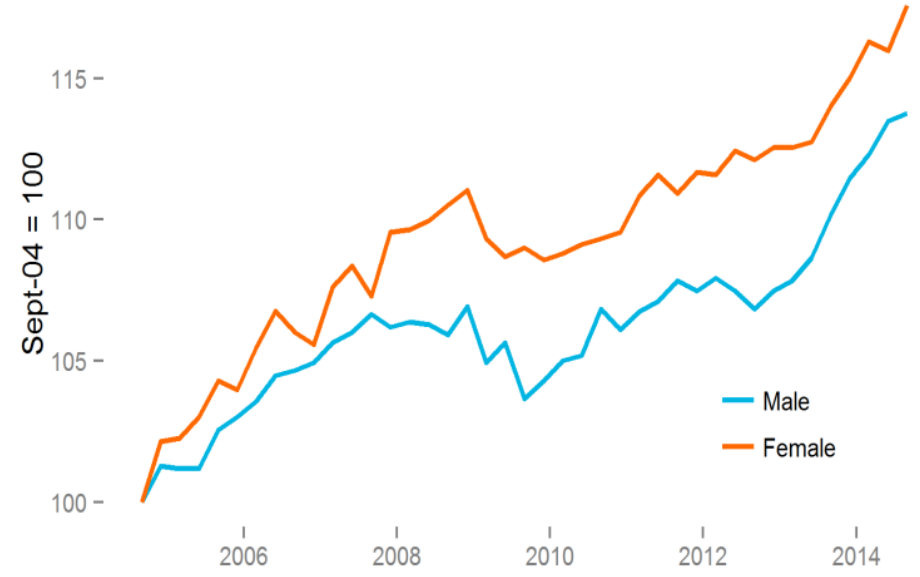

From quarter to quarter there are frequent shifts between maledominated and female-dominated employment growth.

Over the longer term, male employment growth fell relative to female employment growth during the recession, although the growth gap has closed since 2013.

\section{Employment Growth by Industry}

Figure 4: Employment growth by industry 2004-2014

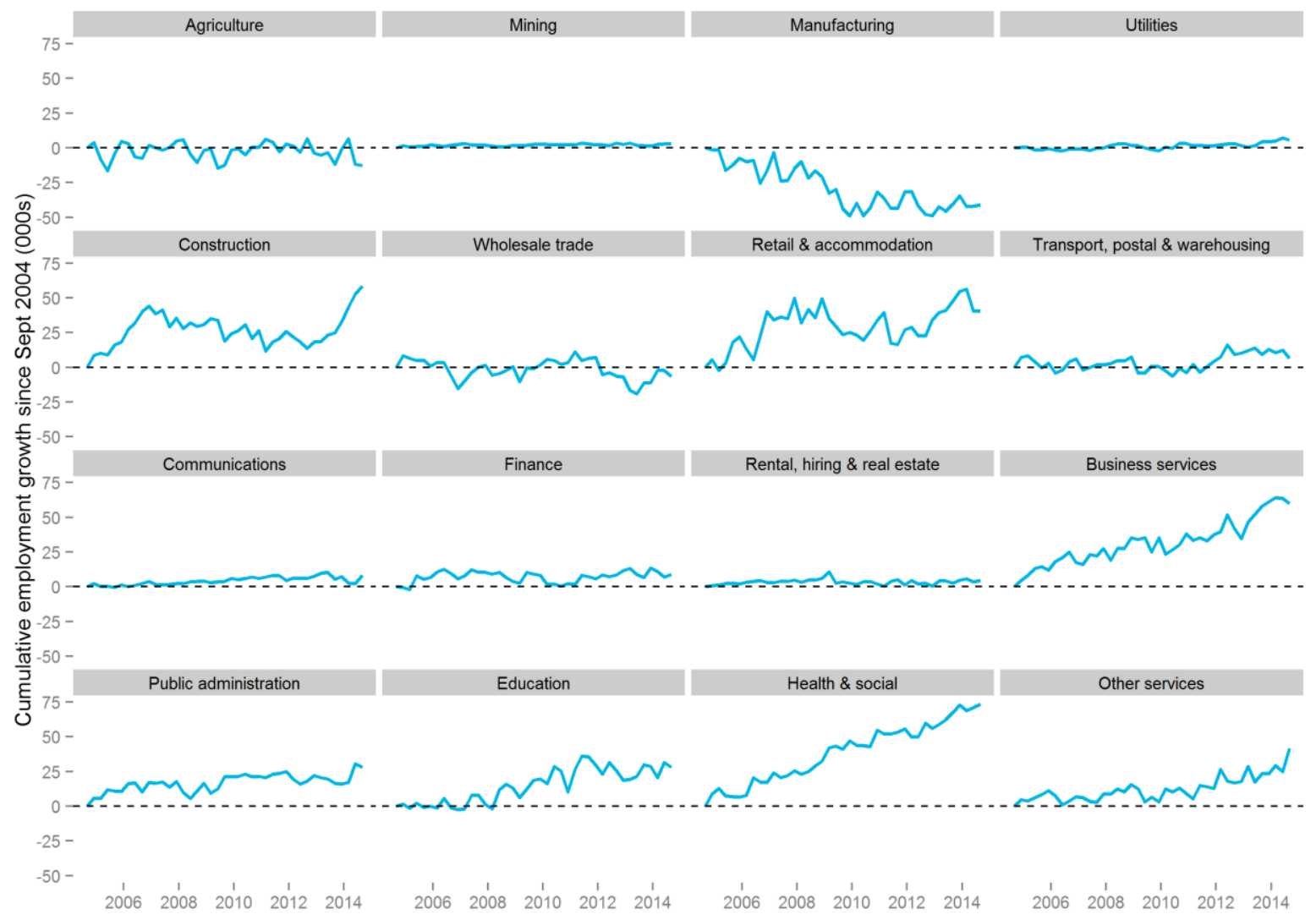

Over the past year, almost half the growth in employment came from the construction industry. While the Canterbury rebuild is a significant driver of demand, most of the increase in construction employment occurred outside of Canterbury.

The chart above shows the cumulative effect of growth in each industry group over the past 10 years. The effect of the global financial crisis is most apprent in construction, and retail and accommodation 
In contrast health and social assistance, and business services continued to grow throughout, while declining manufacturing employment has partially dampened overall growth in this period.

\section{Employment by Region}

Figure 5: Employment growth by region 2004-2014
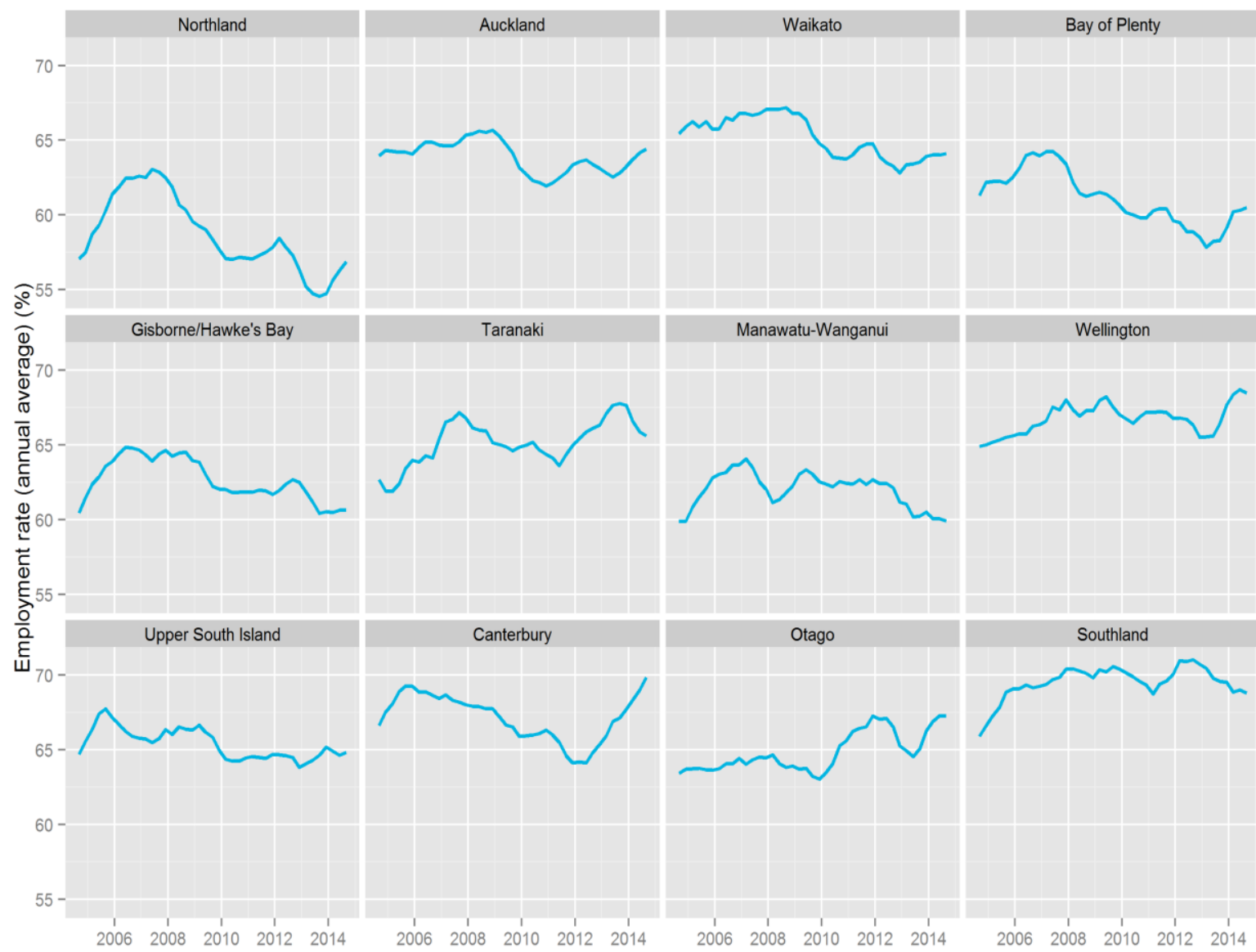

Canterbury accounted for almost half of New Zealand's total employment growth in the year to September, due to growth in construction (up 13,800) and retail trade and accommodation (up $7,800)$. Auckland accounted for a further 22 per cent of total annual employment growth, led by increased employment in construction and wholesale trade.

Employment rates have picked up in most regions over the past year, with the biggest increases coming in Canterbury (up 3.3 percentage points to 70.1 per cent) and Northland (up 2.4 per cent to 57.5 per cent).

Looking at the 10 year charts above, we can see that there are long-term differences in employment rates between the regions. While Canterbury has the highest employment rate at the moment, Southland has been consistently high. This illustrates a recurring pattern where labour market indicators for the South Island (employment and participation rates) have been higher in the South Island than the North, while unemployment rates have been lower particularly during the downturns. 


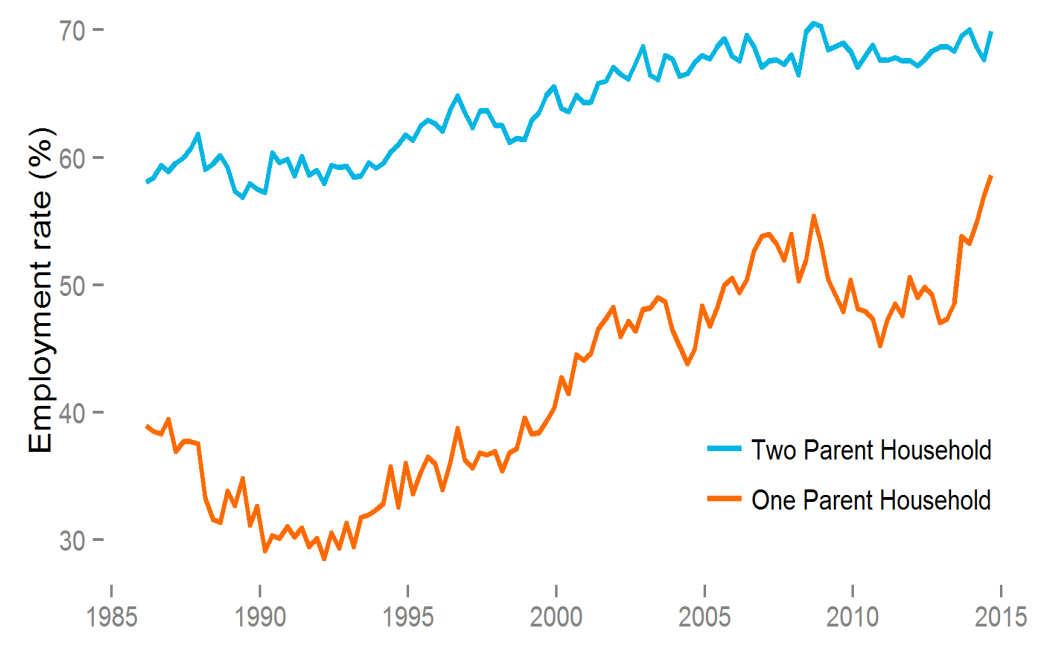

In the September 2014 quarter, there were 122,100 mothers in one-parent households with dependent children. The employment rate for these single mothers was 58.6 per cent, the highest it has been since the series began in 1986 .

The increase was particularly strong for single mothers whose youngest child is older than five. In the past two years, the employment rate for this group of women rose from 60.9 per cent to 70.3 per cent. This increase has been accompanied by changes to Sole Parent Support, requiring beneficiaries with a youngest child older than five to actively seek work. It may also reflect a longer-term upward trend in the employment of single mothers, and recent economic growth - so it could be a return to the previous trend.

\section{Labour Supply}

Table 1: Key labour supply indicators

\begin{tabular}{|l|l|l|l|}
\hline Indicator & September 2014 & Quarterly change & Annual change \\
\hline Labour force & $2,346,000$ & $14,000(+0.6 \%)$ & $57,000(+2.4 \%)$ \\
\hline Working-age population & $3,595,000$ & $15,000(+0.4 \%)$ & $64,000(+1.8 \%)$ \\
\hline Participation rate (\%) & 69.0 & $+0.1 \mathrm{pp}$. & $+0.4 \mathrm{pp}$. \\
\hline
\end{tabular}

Labour supply growth has been strong over the year. - increasing by 57,000, with a 72,000 increase in employment and a 14,000 fall in unemployment. The labour force participation rate remains very high at 69.0 per cent, just below the highest participation rate on record (69.2 per cent, which has been hit twice in the past ten years). 


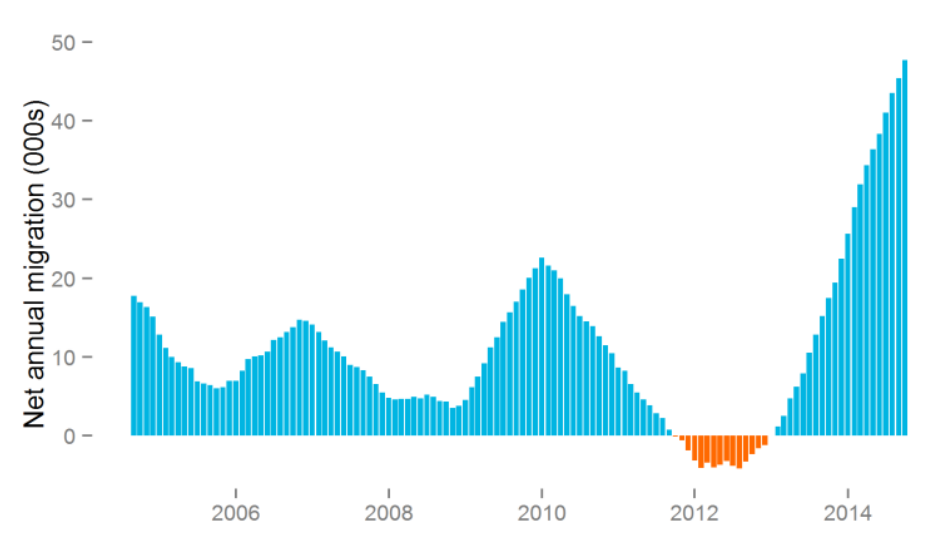

Migration-led population growth has also expanded the supply of labour. The working-age population increased 1.8 per cent over the year, the highest annual increase since June 2004.

In the year to October 2014, New Zealand had a net gain of 47,700 permanent and long-term migrants, the highest level of annual net migration on record.

Arrivals were up 16 per cent over the year and departures down 20 per cent.

Overall migration patterns are largely driven by a decline in net migration of New Zealand citizens to Australia, and a steady increase in arrivals of non-New Zealand citizens. Annual departures of New Zealanders to Australia have declined since 2013, while New Zealand citizens returning from Australia have increased.

Last month was the first month since 1993 where more New Zealanders returned from Australia than left for it. Annual migration to Australia is still several thousand but is falling quickly.

Figure 8: Unemployment

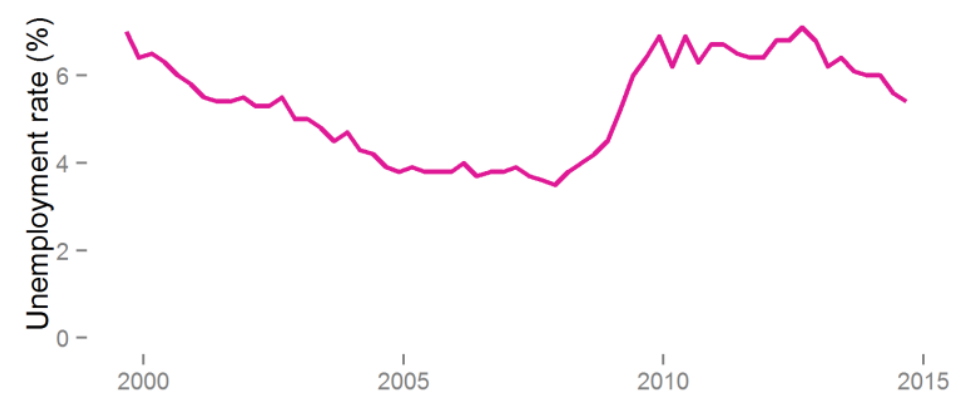

In the September quarter, the number of unemployed people fell by 4,000 (2.8 per cent) to reach 134,000. Together with a smaller rise in the size of the labour force, this caused the unemployment rate to fall by 0.2 percentage points to 5.4 per cent. This is the lowest unemployment rate since March 2009.

\section{Unemployment by Ethnicity}

In the June quarter, the unemployment rates for Māori, Pacific peoples and Europeans reached their lowest level since December 2008. While the unemployment rates for Māori and Pacific peoples ticked up slightly in September, the series is not seasonally adjusted. Over the year to September, there has been a strong decline in Pacific peoples' unemployment rate: from 15.7 per cent to 11.7 per cent. This equates to 4,200 fewer unemployed Pacific peoples. Most of this drop is attributable to lower unemployment for Pacific women. 


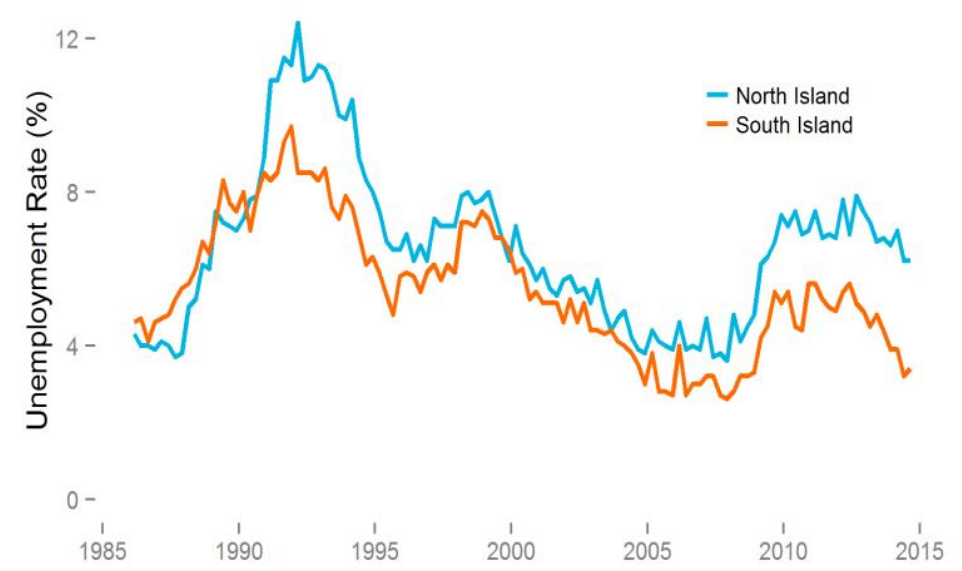

quarter, but remains wide (6.2 per cent and 3.4 per cent respectively).
Over the year to September, unemployment rates fell in every region except Waikato (which recorded a slight increase from 6.1 per cent to 6.2 per cent). The largest falls in unemployment rates were recorded in Southland (from 5.4 per cent to 3.3 per cent) and Gisborne/Hawke's Bay (from 8.5 per cent to 7.0 per cent).

The gap between North Island and South Island unemployment rates narrowed slightly over the

Figure 10: Youth outcomes, the NEET rate 2004-2014

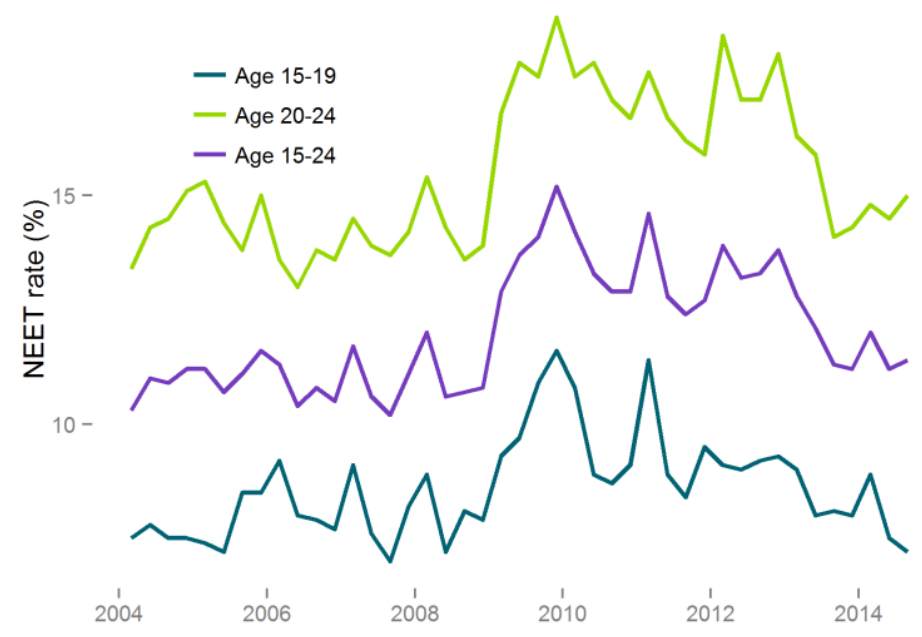

overall NEET rate for 15-24 year olds.
The share of young people who were Not in Education, Employment or Training (the NEET rate) rose slightly over the September quarter, from 11.2 per cent to 11.4 per cent. This increase partly reflects a compositional effect. There are more 20-24 year olds relative to 15-19 year olds than in June. As 20-24 year olds have generally higher NEET rates (and those NEET rates have increased over the quarter) this has increased the

Over the year, the NEET rate for youth aged 15-19 fell 0.9 percentage points to 7.2 per cent, the lowest level since June 2008. The NEET rate for youth aged 20-24 rose 0.9 percentage points over the year to 15.0 per cent. Women contributed more to this increased NEET rate. 
Figure 11: Wage and salary increases, 2004-2014

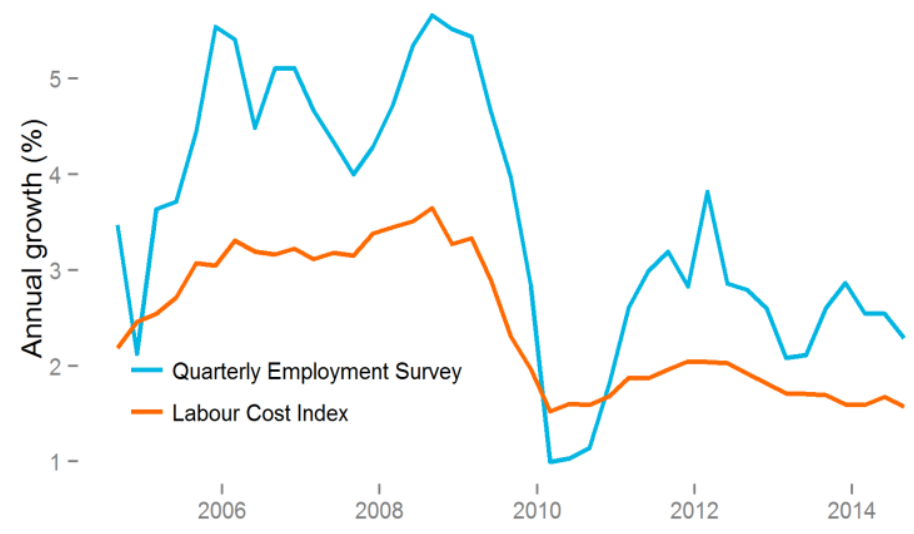

Wage inflation as measured by the Labour Cost Index (LCI) - the same job done to the same standard - fell sharply following the GFC with a lag of about a year and remained around this level since.

Average hourly wages, as measured by the Quarterly Employment Survey (QES), have been much more volatile, reflecting changes in the composition of employment. Hourly rates rose sharply at the start of the GFC as lower-paid jobs were affected more, and then dropped sharply in 2010 as the reverse occurred. However, we can see the same overall pattern in both series with a sharp fall, followed by a weak recovery

Figure 12: Real wage rises 2009-2014

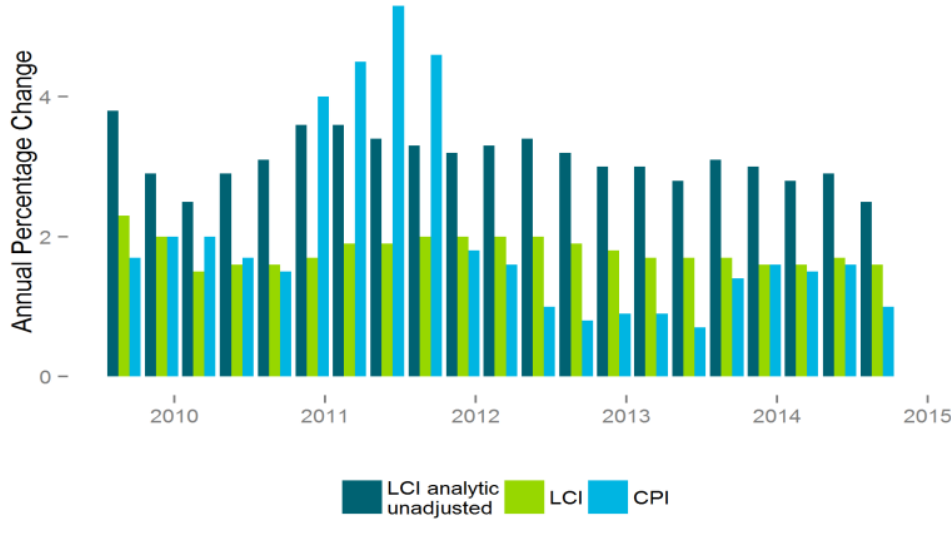

In part this has been due to the low inflation environment since the GFC. Leaving aside the impact of the rise in GST, which shows through over 2010 and 2011, the inflation rate has been noticeably lower over the past few years.

In the latest figures, the annual increase in the official LCI was over half a percent $(0.6 \%)$ above the CPI. And Statistics New Zealand's analytical unadjusted series (which includes productivityrelated pay increases) rose by $1.5 \%$ more than the CPI.

Figure 13: Regional wage growth in the construction industry 2009-2014

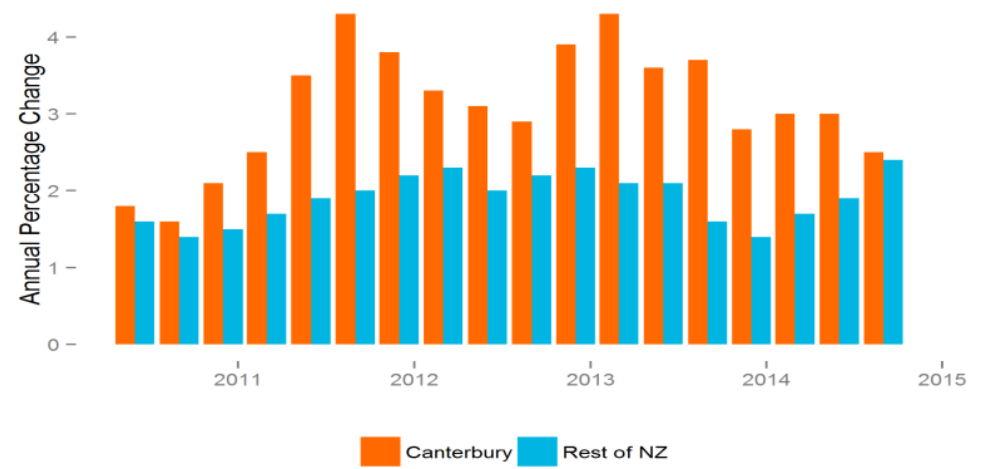

Wage growth in the construction industry has eased in Canterbury, while edging up for the rest of New Zealand. Construction wages in Canterbury increased 2.5 per cent in the year to September, down from the 3.0 per cent annual growth recorded in the year to June. 


\section{Forecasts}

Table 2: Labour market forecasts 2013-2017

\begin{tabular}{|l|l|l|l|l|}
\hline & Actual & \multicolumn{2}{l|}{ Forecast } \\
\hline & 2014 & 2015 & 2016 & 2017 \\
\hline Employment growth (AAPC) & 2.8 & 2.4 & 2.2 & 1.6 \\
\hline Participation rate (\%) & 69.3 & 69.4 & 69.8 & 69.9 \\
\hline Employment rate (\%) & 65.1 & 65.7 & 66.4 & 66.6 \\
\hline Unemployment rate(\%) & 6.0 & 5.3 & 5.1 & 4.8 \\
\hline
\end{tabular}

MBIE forecasts employment growth to remain strong but for growth rates to decline over the next three years. The unemployment rate is forecast to drop below 5.0 per cent by March 2017 .

The main driver of the employment forecasts is GDP growth The 2014 Pre-Election economic update (PREFU) by the Treasury forecast that economic growth will peak $3.6 \%$ in the year to March 2015 and then slow to $2.2 \%$ over the next 2 years.

\section{References}

Ministry of Business Innovation and Employment. (2014). Quarterly Labour Market report, September 2014, http://dol.govt.nz/publications/lmr/labour-market-report.asp 